\title{
Integrated Use of Herbicide and Crop Mulch in Suppressing Weed Growth in a Dry-Seeded Rice System
}

\author{
Bhagirath Singh Chauhan*, Seth Bernard Abugho \\ Crop and Environmental Sciences Division, International Rice Research Institute, Los Baños, Philippines. \\ Email: *b.chauhan@irri.org
}

Received June $4^{\text {th }}, 2013$; revised July $4^{\text {th }}, 2013$; accepted July $20^{\text {th }}, 2013$

Copyright (C) 2013 Bhagirath Singh Chauhan, Seth Bernard Abugho. This is an open access article distributed under the Creative Commons Attribution License, which permits unrestricted use, distribution, and reproduction in any medium, provided the original work is properly cited.

\begin{abstract}
Dry-seeded rice production systems are increasing in many Asian countries because of labor and water scarcities. However, weeds are the main biological constraints in these systems. Herbicides are widely used to manage weeds but they do not provide effective weed control. The use of crop residue as mulch can suppress weed emergence and weed biomass but mulch alone does not provide effective weed control. The integrated use of herbicide and mulch, however, could provide more effective and sustainable weed control in dry-seeded rice systems. A study was conducted in two consecutive rice growing seasons to evaluate the combined effect of herbicide (treated and nontreated) and rice straw mulch $\left(0,2\right.$, and $\left.4 \mathrm{t}^{-\mathrm{ha}^{-1}}\right)$ on weed growth and rice yield in a dry-seeded rice system. In the nontreated plots, weed biomass decreased with increases in mulch amounts, whereas weed biomass in the herbicide-treated plots was similar at different mulch amounts. Overall, herbicide treatments provided better weed control than the mulch treatments. In the nontreated plots, grain yield was similar at different mulch amounts, whereas grain yield in the herbicide-treated plots was greater when the field was mulched with $4 \mathrm{t}^{\mathrm{h}} \mathrm{ha}^{-1}$ of rice straw than with no mulch or mulched with only $2 \mathrm{t} \cdot \mathrm{ha}^{-1}$ of rice straw. The results suggest that integrated use of mulch and herbicides can help weed control and increase crop yield in dry-seeded rice.
\end{abstract}

Keywords: Grain Yield; Integrated Weed Management; Rice Residue; Weed Biomass

\section{Introduction}

Rice is one of the most important crops in the world. More than $90 \%$ of the world's rice is grown and consumed in Asia. In most Asian countries, rice is commonly grown by manual transplanting of seedlings into puddled soil [1-3]. Recently, however, there has been a shifting of puddled-transplanted rice to seeded rice in many Asian regions. The main reasons for this shift are labor and water scarcities. The farm labor wage has increased significantly because of the migration of labor from rural to urban areas. In addition, it is difficult to acquire labor at the critical time of seedling transplanting. By the time labor is available, the critical time of transplanting has already passed, which results in a decline in grain yield. Puddling and transplanting operations in the puddled-transplanted rice production system consume a considerable amount of water [3]. It was predicted that South and Southeast Asia may experience physical and

${ }^{*}$ Corresponding author. economic water scarcities in the near future [4,5]. Therefore, to solve the problems of labor and water scarcities, farmers in many Asian countries are shifting toward seeded rice systems, especially mechanized sowing of dry-seeded rice $[1,6]$.

Seeded rice systems have several advantages over puddled-transplanted rice systems. However, weeds are the number-one biological constraint to the production of seeded rice systems because of the absence of standing water at crop emergence to suppress weed emergence and the absence of a seedling size advantage to suppress weed growth $[1,7]$. Rice cultivars capable of emerging under anaerobic conditions are not available in Asia and therefore fields can be flooded only after crop emergence [1].

In Asia, the intensification of rice-based cropping systems has increased the production of crop residues and, in the absence of an effective residue management strategy, farmers burn crop residues in the field [8]. Burning not only results in a loss of nutrients but also causes at- 
mospheric pollution that poses a threat to ecosystem and human health [2]. Many Asian governments have banned residue burning and other governments may soon follow [8].

Crop residues can be used as mulch to suppress weed emergence and weed growth $[9,10]$. Crop residues are usually retained in zero-till fields [1,11]; however, the residues can also be used as mulch after conventional tillage [8]. This involves temporarily removing the residues from the field and then returning them to the field after crop planting. Many large farmers may not follow this practice, but this option may be more feasible for farmers with small landholdings [8,12]. Herbicides are widely used to manage weeds in dry-seeded rice systems; however, herbicides alone cannot provide effective and season-long weed control. Therefore, there is a need to integrate herbicide use with other weed management strategies [9,13-15]. The use of residue as mulch can suppress weed growth to some extent in seeded rice, but the combined use of herbicide and mulch may suppress weeds more effectively. Therefore, a field study was conducted to evaluate the combined effects of herbicide and mulch on weed growth and rice yield in a dry-seeded system.

\section{Materials and Methods}

A study was conducted in a field during the dry and wet seasons of 2012 at the International Rice Research Institute, Los Baños, Philippines. Soil at the experimental site had a $\mathrm{pH}$ of 6.8 and contained organic carbon of $1.0 \%$, sand of $28 \%$, silt of $43 \%$, and clay of $29 \%$. The field was cultivated twice before crop sowing. Rice (cv. Rc222) was planted at a seed rate of $50 \mathrm{~kg} \cdot \mathrm{ha}^{-1}$ with a combine drill fitted with knife-point openers. The crop was sown in rows $20 \mathrm{~cm}$ apart on January 7 and May 21, 2012. Phosphorus and potassium were applied at $40 \mathrm{~kg}$ $\mathrm{P}_{2} \mathrm{O}_{5} \cdot \mathrm{ha}^{-1}$ and $40 \mathrm{~kg} \mathrm{~K}{ }_{2} \mathrm{O} \cdot \mathrm{ha}^{-1}$, respectively, at crop sowing. Nitrogen was applied in three splits: $54 \mathrm{~kg} \mathrm{~N} \cdot \mathrm{ha}^{-1}$ at 14 days after sowing (DAS), $54 \mathrm{~kg} \mathrm{~N} \cdot \mathrm{ha}^{-1}$ at $35 \mathrm{DAS}$, and $72 \mathrm{~kg} \mathrm{~N} \cdot \mathrm{ha}^{-1}$ at $60 \mathrm{DAS}$. The field was irrigated immediately after sowing and then as required. There was no water stress at any stage of the crop. Because of upland conditions and the absence of a hard pan, the field never experienced flooding.

In the study, there were two herbicide (nontreated and treated) and three rice straw mulch $\left(0,2\right.$, and $\left.4 \mathrm{t} \cdot \mathrm{ha}^{-1}\right)$ treatments. The experiments in each season were arranged in a randomized split-plot design with herbicide as the main plots and mulch amount as the subplots. Each treatment was replicated four times in each season. In the herbicide-treated plots, oxadiazon $\left(0.5 \mathrm{~kg} \cdot \mathrm{ai}^{\circ} \mathrm{ha}^{-1}\right.$ at 1 DAS followed by a commercial mixture of fenoxaprop plus ethoxysulfuron $\left(0.45 \mathrm{~kg} \cdot \mathrm{ai} \cdot \mathrm{ha}^{-1}\right)$ at $21 \mathrm{DAS}$ were applied with a knapsack sprayer that delivered $220 \mathrm{~L} \cdot \mathrm{ha}^{-1}$ of spray solution through flat-fan nozzles at a spray pressure of $140 \mathrm{kPa}$. Air-dried rice (cv. Rc222) mulch (straw having leaves and stems) was spread on the soil surface at 3 DAS at 0,2 , and $4 \mathrm{t} \cdot \mathrm{ha}^{-1}$.

Weed density and biomass were evaluated at 35 DAS (14 d after the spray of post-emergence herbicide) by placing two $40 \mathrm{~cm} \times 40 \mathrm{~cm}$ quadrats in each plot. At crop harvest, it was not possible to count weed density; therefore, only weed biomass was determined. Weeds were cut at ground level, washed with tap water, and then counted. The biomass was determined after drying the samples in an oven at $70^{\circ} \mathrm{C}$ for 72 hours. At crop maturity, the number of rice panicles was counted from four randomly selected 1-meter rows. The plot size was $12 \mathrm{~m}^{2}$ and the crop was harvested from a 4- $\mathrm{m}^{2}$ area on May 1 and September 18, 2012. Grain yield was converted to $\mathrm{t} \cdot \mathrm{ha}^{-1}$ at $14 \%$ moisture content.

All data were analyzed using ANOVA to evaluate differences between treatments, and the means were separated using LSD at 5\% [16]. Weed density and biomass data were subjected to transformation; however, the transformation did not improve the homogeneity of variance. Therefore, nontransformed data were used for analysis. In addition, the relationships between grain yield $\left(\mathrm{t} \cdot \mathrm{ha}^{-1}\right)$ and weed biomass $\left(\mathrm{g} \cdot \mathrm{m}^{-2}\right)$ at harvest and between grain yield $\left(\mathrm{t} \cdot \mathrm{ha}^{-1}\right)$ and rice panicles $\left(\mathrm{no} \cdot \mathrm{m}^{-2}\right)$ was assessed using exponential and linear curves, respectively (Sigma Plot 10.0).

\section{Results and Discussion}

The common weed species at the experimental site were yellow cleome (Cleome rutidosperma Dc.), bermudagrass (Cynodon dactylon L.), rice flatsedge (Cyperus iria L.), purple nutsedge (C. rotundus L.), crow foot grass [Dactyloctenium aegyptium (L.) Willd.], southern crabgrass [Digitaria ciliaris (Retz.) Koel.], junglerice [Echinochloa colona (L.) Link], goosegrass [Eleusine indica (L.) Gaertn.], Chinese sprangletop [Leptochloa chinensis (L.) Nees], common purslane (Portulaca oleracea L.), niruri (Phyllanthus niruri L.), and horse purslane (Trianthema portulacastrum L.). Only total weed density and weed biomass data are presented in this article.

The interaction effect of herbicide and mulch treatments on total weed density was nonsignificant in both seasons. However, weed density was influenced by individual effects of herbicide and mulch (Table 1). In both seasons, as expected, weed density was higher in the nontreated plots than in the herbicide-treated plots. Weed density was significantly higher (352 and 525 plants $\mathrm{m}^{-2}$ in dry and wet seasons) when no mulch was applied. An increase in mulch amount reduced weed density; however, the density was similar between the mulch amounts of 2 and $4 \mathrm{t} \cdot \mathrm{ha}^{-1}$. 
Table 1. Effect of herbicide and mulch amounts on total weed density at $35 \mathrm{~d}$ after sowing in a dry-seeded rice system.

\begin{tabular}{ccc}
\hline \multirow{2}{*}{ Treatments } & \multicolumn{2}{c}{ Total weed density } \\
\cline { 2 - 3 } & Dry season & Wet season \\
\cline { 2 - 3 } Herbicide & & \\
Nontreated & 315 & 639 \\
Treated & 78 & 125 \\
LSD $(\mathrm{P}=0.05)$ & 141 & 154 \\
Mulch amount & & \\
0 t $\cdot \mathrm{ha}^{-1}$ & 352 & 525 \\
2 t $\cdot \mathrm{ha}^{-1}$ & 170 & 352 \\
$4 \mathrm{t}^{-1} \cdot \mathrm{ha}^{-1}$ & 67 & 270 \\
LSD $(\mathrm{P}=0.05)$ & 145 & 129 \\
\hline
\end{tabular}

Abbreviations: LSD, least significant difference.

The interaction effect of herbicide and mulch amounts was significant on total weed biomass at 35 DAS and this was true in both seasons (Table 2). Weed biomass at each mulch amount was greater in the nontreated plots than in the herbicide-treated plots, except in the dry season, in which weed biomass at $4 \mathrm{t} \cdot \mathrm{ha}^{-1}$ of mulch amount was statistically similar between the herbicide-treated and nontreated plots (Table 2). In the nontreated plots, weed biomass was highest in the no-mulch treatment and it decreased with increases in mulch amounts. In the dry season, for example, the no-mulch treatment had a weed biomass of $61 \mathrm{~g} \cdot \mathrm{m}^{-2}$ and the biomass declined to 41 and $19 \mathrm{~g} \cdot \mathrm{m}^{-2}$ when mulch was added at 2 and $4 \mathrm{t} \cdot \mathrm{ha}^{-1}$, respectively. A similar response was observed in the wet season; however, weed biomass in the wet season was 4 to 6 times higher than in the dry season. In the herbicide-treated plots, on the other hand, weed biomass was similar at different mulch amounts at 35 DAS (Table 2). These results suggest that weed biomass can be significantly reduced by the use of rice straw as mulch, particularly where herbicides are not widely used or partial weed control is expected. However, the use of mulch alone did not completely suppress the growth of weeds as the plots mulched with $4 \mathrm{t} \cdot \mathrm{ha}^{-1}$ of straw still had onethird to one-half of the weed biomass compared with the plots with no mulch. The combination of herbicide spray and mulch reduced weed biomass compared with the use of herbicide alone; however, the difference in weed biomass was statistically similar whether herbicide was used alone or combined with mulch.

The results suggest that the application of oxadiazon followed by fenoxaprop plus ethoxysulfuron provided
Table 2. Interaction effect of herbicide and mulch amounts on total weed biomass at $\mathbf{3 5} \mathbf{d}$ after sowing in a dry-seeded rice system.

\begin{tabular}{|c|c|c|c|}
\hline \multirow{2}{*}{ Mulch amounts } & \multicolumn{2}{|c|}{ Total weed biomass } & \multirow{2}{*}{$\begin{array}{c}\mathrm{LSD}^{\mathrm{a}} \\
(\mathrm{P}=0.05)\end{array}$} \\
\hline & Nontreated & Treated & \\
\hline $\mathrm{t} \cdot \mathrm{ha}^{-1}$ & 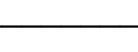 & & \\
\hline \multicolumn{4}{|l|}{ Dry season } \\
\hline 0 & 60.5 & 14.0 & 25.7 \\
\hline 2 & 40.6 & 1.7 & \\
\hline 4 & 19.0 & 0.4 & \\
\hline $\operatorname{LSD}^{\mathrm{b}}(\mathrm{P}=0.05)$ & & & \\
\hline \multicolumn{4}{|l|}{ Wet season } \\
\hline 0 & 245.6 & 34.5 & 40.2 \\
\hline 2 & 165.4 & 12.0 & \\
\hline 4 & 118.1 & 6.4 & \\
\hline $\operatorname{LSD}^{\mathrm{b}}(\mathrm{P}=0.05)$ & & & \\
\hline
\end{tabular}

${ }^{\mathrm{a}} \mathrm{LSD}$ for comparing means within a mulch amount; ${ }^{b} \mathrm{LSD}$ for comparing means within a herbicide treatment. Abbreviations: LSD, least significant difference.

effective weed control, at least until 35 DAS. In a recent study in the Philippines, this combination of herbicides provided excellent weed control in dry-seeded rice sown after tillage or under zero-till conditions [6]. Oxadiazon is used as a preemergence herbicide in dry-seeded rice to control annual grasses and broadleaf weeds $[6,17,18]$. In other studies, too, oxadiazon provided excellent weed control $[19,20]$.

It is well known that crop straw as mulch can substantially suppress the growth of many weeds. Some of the reasons for weed suppression by mulch are the release of allelo chemicals, reductions in light transmittance, temperature fluctuations, and a physical barrier by the mulch cover [21,22]; however, the rice cultivar used in our study is not known for its allelopathic effects.

In both seasons, grain yield was significantly affected by the interaction between herbicide and mulch treatments (Table 3). As expected, grain yield was always higher in the herbicide-treated plots than in the nontreated plots. In the nontreated plots, grain yield was similar at different mulch amounts, whereas grain yield in the herbicide-treated plots was greater when the field was mulched with $4 \mathrm{t} \cdot \mathrm{ha}^{-1}$ of rice straw than without mulch or mulched with only $2 \mathrm{t} \cdot \mathrm{ha}^{-1}$ of rice straw. In the nontreated plots, grain yield in the dry season was from 1.1 to $1.3 \mathrm{t}^{\mathrm{h}} \mathrm{ha}^{-1}$, whereas grain yield in the wet season was only 0.2 to $0.3 \mathrm{t} \cdot \mathrm{ha}^{-1}$. Such low yields in the nontreated plots in the wet season were mainly due to high weed pressure. Our results support this observation as 
Table 3. Interaction effect of herbicide and mulch amounts on grain yield in a dry-seeded rice system.

\begin{tabular}{|c|c|c|c|}
\hline \multirow{2}{*}{$\begin{array}{l}\text { Mulch } \\
\text { amounts }\end{array}$} & \multicolumn{2}{|c|}{ Grain yield } & \multirow{2}{*}{$\begin{array}{c}\mathrm{LSD}^{\mathrm{a}} \\
(\mathrm{P}=0.05)\end{array}$} \\
\hline & Nontreated & Treated & \\
\hline$t \cdot h a^{-1}$ & 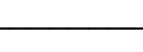 & & \\
\hline \multicolumn{4}{|l|}{ Dry season } \\
\hline 0 & 1.05 & 2.15 & 0.21 \\
\hline 2 & 1.09 & 2.17 & \\
\hline 4 & 1.27 & 2.79 & \\
\hline $\begin{array}{c}\text { LSD }^{b} \\
(\mathrm{P}=0.05)\end{array}$ & \multicolumn{2}{|c|}{0.23} & \\
\hline \multicolumn{4}{|l|}{ Wet season } \\
\hline 0 & 0.15 & 1.14 & 0.97 \\
\hline 2 & 0.22 & 2.05 & \\
\hline 4 & 0.28 & 3.23 & \\
\hline $\begin{array}{c}\text { LSD }^{\mathrm{b}} \\
(\mathrm{P}=0.05)\end{array}$ & \multicolumn{2}{|c|}{1.00} & \\
\hline
\end{tabular}

${ }^{a}$ LSD for comparing means within a mulch amount; ${ }^{\mathrm{b}} \mathrm{LSD}$ for comparing means within a herbicide treatment. Abbreviations: LSD, least significant difference.

grain yield was negatively correlated $(\mathrm{P}<0.001)$ with weed biomass at crop harvest (Figures 1(a) and (b)). This relationship occurred irrespective of the herbicide and mulch treatments; however, the relationship was slightly stronger in the wet season $\left(R^{2}=0.65\right)$ than in the dry season $\left(R^{2}=0.60\right)$. Grain yield was also highly correlated $(\mathrm{P}<0.001)$ with rice panicle number (Figures 1(c) and (d)). There was a positive and linear relationship between rice grain yield and rice panicle number, with $56 \%$ (dry season) to $80 \%$ (wet season) of the variation in grain yield explained by the relationship.

In the herbicide-treated plots, the integrated use of herbicide and high amounts of mulch $\left(4 \mathrm{t}^{-h^{-1}}\right)$ resulted in the highest grain yield, that is, 2.8 to $3.2 \mathrm{t}^{\mathrm{h}} \mathrm{ha}^{-1}$. Compared with the treatment in which only herbicide was applied, the best combination (herbicide plus $4 \mathrm{t} \cdot \mathrm{ha}^{-1}$ of mulch) resulted in $30 \%$ greater yield in the dry season and $180 \%$ greater yield in the wet season. These results support previous suggestions that integrating herbicide use with other weed management strategies could result in a greater yield advantage over the use of herbicide alone.

Our results suggest that the use of rice straw as mulch can suppress seedling emergence and weed growth $[9,10$, 23-28]. Herbicide is an important component for managing weeds in dry-seeded rice systems; however, herbicide alone may not provide complete and season-long weed control [1]. Therefore, integrating herbicide use with other weed management strategies may increase weed control and grain yield in seeded rice systems. We did

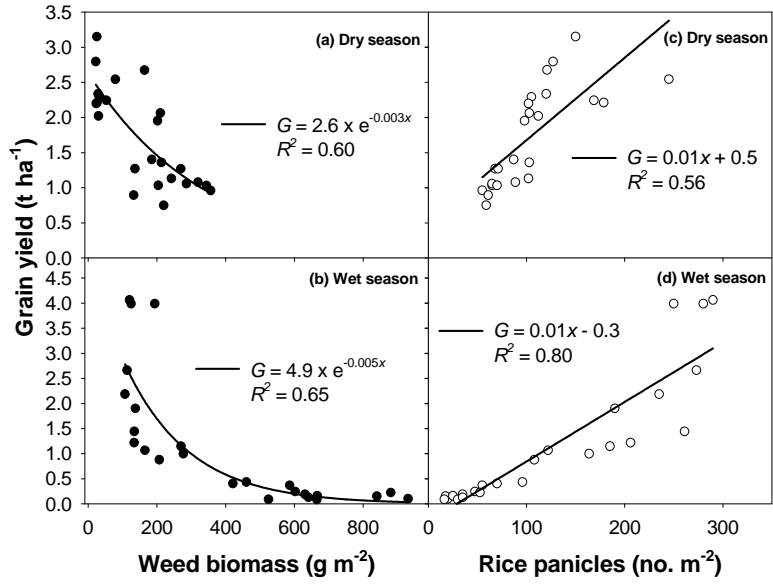

Figure 1. Relationships between grain yield and weed biomass at crop harvest (a and $b$ ) and between grain yield and rice panicles (c and d) in dry (a and c) and wet (b and d) seasons.

not sterilize the straw before using in the field and there were no pest activities observed in the study. However, crop residue may play an important role in the carryover of pests from one crop to another. Therefore, it is important to examine the straw before using in the field as mulch. We used a mulch amount of only up to $4 \mathrm{t} \cdot \mathrm{ha}^{-1}$ but additional rice straw could be brought in from other fields to achieve greater weed control [10]. Such an option would be more practical for small-holding farmers who do not have enough resources to use multiple herbicides or those who practice organic farming [8]. As rice seeds are usually larger than weed seeds, the use of high mulch amounts could offer an important opportunity for weed management. In India, it was reported that the seeding of rice into a residue load of up to $7 \mathrm{t} \cdot \mathrm{ha}^{-1}$ is possible [25]. Our results also suggest that farmers do not need to burn rice straw for residue management in intensive cropping systems. In addition to the combined use of herbicide and rice straw as mulch, the use of the stale seedbed practice with weed-competitive cultivars could be included in integrated weed management programs for dry-seeded rice systems in Asia.

\section{Conclusion}

In Asia, dry-seeded rice production systems are increasing because of labor and water scarcities. In these systems, however, weeds are the main biological constraints. The results of our study showed that integrated use of mulch and herbicides can help weed control and increase crop yield in dry-seeded rice systems.

\section{REFERENCES}

[1] B. S. Chauhan, "Weed Ecology and Weed Management Strategies for Dry-Seeded Rice in Asia," Weed Technol- 
ogy, Vol. 26, No. 1, 2012, pp. 1-13. doi:10.1614/WT-D-11-00105.1

[2] B. S. Chauhan, G. Mahajan, V. Sardana, J. Timsina and M. L. Jat, "Productivity and Sustainability of the RiceWheat Cropping System in the Indo-Gangetic Plains of the Indian Subcontinent: Problems, Opportunities and Strategies," Advances in Agronomy, Vol. 117, 2012, pp. 315-369. doi:10.1016/B978-0-12-394278-4.00006-4

[3] G. Mahajan, B. S. Chauhan, J. Timsina, P. P. Singh and K. Singh, "Crop Performance and Water- and Nitrogen-Use Efficiencies in Dry-Seeded Rice in Response to Irrigation and Fertilizer Amounts in Northwest India," Field Crops Research, Vol. 134, 2012, pp. 59-70. doi:10.1016/j.fcr.2012.04.011

[4] T. P. Tuong and B. A. M. Bouman, "Rice Production in Water-Scarce Environments," In: J. W. Kijne, R. Barker and D. Molden, Eds., Water Productivity in Agriculture: Limits and Opportunities for Improvements, CABI Publishing, Collingwood, 2003, pp. 53-67. doi:10.1079/9780851996691.0053

[5] T. P. Tuong, B. A. M. Bouman and M. Mortimer, "More Rice, Less Water: Integrated Approaches for Increasing Water Productivity in Irrigated Rice-Based Systems in Asia," Plant Production Science, Vol. 8, No. 3, 2005, pp. 231-241. doi:10.1626/pps.8.231

[6] B. S. Chauhan and J. Opeña, "Effect of Tillage Systems and Herbicides on Weed Emergence, Weed Growth and Grain Yield in Dry-Seeded Rice Systems," Field Crops Research, Vol. 137, 2012, pp. 56-69.

[7] B. S. Chauhan and D. E. Johnson, "The Role of Seed Ecology in Improving Weed Management Strategies in the Tropics," Advances in Agronomy, Vol. 105, 2010, pp. 221-262. doi:10.1016/S0065-2113(10)05006-6

[8] Bijay-Singh, Y. H. Shan, S. E. Johnson-Beebout, Yadvinder-Singh and R. J. Buresh, "Crop Residue Management for Lowland Rice-Based Cropping Systems in Asia," Advances in Agronomy, Vol. 98, 2008, pp. 117-199. doi:10.1016/S0065-2113(08)00203-4

[9] B. S. Chauhan, R. G. Singh and G. Mahajan, "Ecology and Management of Weeds under Conservation Agriculture: A Review," Crop Protection, Vol. 38, 2012, pp. 5765. doi:10.1016/j.cropro.2012.03.010

[10] C. L. Mohler and J. R. Teasdale, "Response of Weed Emergence to Rate of Vicia villosa Roth and Secale cereale L. Residue," Weed Research, Vol. 33, No. 6, 1993, pp. 487-499. doi:10.1111/j.1365-3180.1993.tb01965.x

[11] P. Hobbs, "Conservation Agriculture: What Is It and Why Is It Important for Future Sustainable Food Production?" Journal of Agricultural Science, Vol. 145, No. 2, 2007 , pp. 127-137. doi:10.1017/S0021859607006892

[12] Y. Tang, J. Zheng, G. Huang and J. Du, "Study on Permanent-Bed-Planting with Double Zero Tillage for Rice and Wheat in Sichuan Basin," Proceedings of the 4th International Crop Science Congress, Brisbane, 2004. http://www.regional.org.au/au/cs/2004/poster/1/2/1320_ta ngaa.htm

[13] B. S. Chauhan, G. Gill and C. Preston, "Tillage System Effects on Weed Ecology, Herbicide Activity and Persistence: A Review," Australian Journal of Experimental
Agriculture, Vol. 46, No. 12, 2006, pp. 1557-1570. doi:10.1071/EA05291

[14] M. A. Locke, K. N. Reddy and R. M. Zablotowicz, "Weed Management in Conservation Crop Production Systems," Weed Biology and Management, Vol. 2, No. 3, 2002, pp. 123-132. doi:10.1046/j.1445-6664.2002.00061.x

[15] A. N. Rao and A. Nagamani, "Integrated Weed Management in India-Revisited," Indian Journal of Weed Science, Vol. 42, 2010, pp. 123-135.

[16] GenStat 8.0, "GenStat Release 8 Reference Manual," VSN International, Oxford, 2005, p. 343.

[17] K. Ampong-Nyarko and S. K. De Datta, "A Handbook for Weed Control in Rice," International Rice Research Institute, Los Baños, 1991, p. 113.

[18] B. S. Chauhan and D. E. Johnson, "Growth Response of Direct-Seeded Rice to Oxadiazon and Bispyribac-Sodium in Aerobic and Saturated Soils," Weed Science, Vol. 59, No. 1, 2011, pp. 119-122. doi:10.1614/WS-D-10-00075.1

[19] B. S. Chauhan and S. B. Abugho, "Weed Management in Mechanized-Sown, Zero-Till Dry-Seeded Rice," Weed Technology, Vol. 27, No. 1, 2013, pp. 28-33. doi:10.1614/WT-D-12-00088.1

[20] D. B. Ishaya, S. A. Dadari and J. A. Y. Shebayan, "Evaluation of Herbicides for Weed Control in Three Varieties of Upland Rice (Oryza sativa L.) in the Nigerian Savannah," Crop Protection, Vol. 26, No. 10, 2007, pp. 14901495. doi:10.1016/j.cropro.2006.12.015

[21] W. E. Dyer, "Exploiting Weed Seed Dormancy and Germination Requirements through Agronomic Practices. Weed Science, Vol. 43, 1995, pp. 498-503.

[22] J. R. Teasdale and C. L. Mohler, "Light Transmittance, Soil Temperature and Soil Moisture under Residue of Hairy Vetch and Rye," Agronomy Journal, Vol. 85, No. 3, 1993, pp. 673-680. doi:10.2134/agronj1993.00021962008500030029x

[23] B. S. Chauhan and G. Mahajan, "Role of Integrated Weed Management Strategies in Sustaining Conservation Agriculture Systems," Current Science, Vol. 103, 2012, pp. 135-136.

[24] R. Gopal, R. K. Jat, R. K. Malik, V. Kumar, M. M. Alam, M. L. Jat, M. A. Mazid, Y. S. Saharawat, A. McDonald and R. Gupta, "Direct Dry Seeded Rice Production Technology and Weed Management in Rice Based Systems. Technical Bulletin," International Maize and Wheat Improvement Center, New Delhi, 2010, p. 28.

[25] R. K. Gupta, J. K. Ladha, S. Singh, R. Singh, M. L. Jat, Y. Saharawat, V. P. Singh, S. S. Singh, G. Singh, G. Sah, M. Gathala, R. K. Sharma, M. S. Gill, M. Alam, H. M. U. Rehman, U. P. Singh, R. A. Mann, H. Pathak, B. S. Chauhan, P. Bhattacharya and R. K. Malik, "Production Technology for Direct Seeded Rice," In: Rice-Wheat Consortium Technical Bulletin, Rice-Wheat Consortium for the Indo-Gangetic Plains, New Delhi, 2006, p. 16.

[26] R. A. Liebl and A. D. Worsham, "Tillage and Mulch Effects on Morningglory (Ipomoea spp.) and Certain Other Weed Species," Proceedings of the Southern Weed Science Society, Vol. 36, 1983, pp. 405-414. 
[27] C. L. Mohler, "Effects of Tillage and Mulch on Weed Biomass and Sweet Corn Yield," Weed Technology, Vol. 5, 1991, pp. 545-552.

[28] C. L. Mohler and M. B. Calloway, "Effects of tillage and mulch on the emergence and survival of weeds in sweet corn," Journal of Applied Ecology, Vol. 29, No. 1, 1992, pp. 21-34. doi:10.2307/2404343 